\title{
Notes on habitat and ex situ conservation of Acanthophippium striatum Lindley - a threatened terrestrial Orchid from Arunachal Pradesh, India
}

\author{
Jumter Nyorak ${ }^{1,3}$, Yani Nyodu ${ }^{1}$ and V. K. Jawal ${ }^{2}$ \\ ${ }^{1}$ Orchid Research Centre, Tippi, 790 114, West Kameng, Arunachal Pradesh, India \\ ${ }^{2}$ Divisional Forest Office, Khellong Forest Division, Bhalukpong 790114, West Kameng, \\ Arunachal Pradesh, India \\ ${ }^{3}$ Corresponding author, e-mail: jumternyorak16@gmail.com
}

[Received 10.10.2020; Revised 16.12.2020; Accepted 18.12.2020; Published 31.12.2020]

\begin{abstract}
Acanthophippium striatum Lindl., a rare and threatened terrestrial orchid, is described with discussion on its rarity and conservation status in Arunachal Pradesh. The photographs of vegetative and floral parts are provided for its identification.
\end{abstract}

Key words: Acanthophippium striatum, Threatened species, Ex-situ Conservation.

\section{INTRODUCTION}

Acanthophippium Blume, is one of the terrestrial genera of the family Orchidaceae, with about twelve species distributed mainly in Southeast Asia from Sri Lanka, Nepal, Japan and India, all over the Malaysian Archipelago and in many islands of the Pacific (Thomas 1997; Su, H.J. 2000). The genus can be distinguished from allied genera by its characteristic jug-shaped flowers by which it is commonly known as "Striped Jug Orchid". In India, the genus is represented by three species, out of which two occur in Arunachal Pradesh (Hegde 1984; Rao 2010). The habit is fairly uniform throughout the genus, and most of the diagnostic features are present in the flowers.

Acanthophippium striatum Lindl. is highly variable, especially in flower size. It differs from allied species in having solitary leaf, spur-like mentum and small-size mid-lobe of lip (Thomas 1997). It is one of the rare and ornamental species among the orchids reported so far from North-East India (Kataki et al.1984; Deori \& Das 1979; Gogoi 2012). In recent past, this species could be spotted in Arunachal Pradesh only from very small pockets in the natural habitats. During the field survey, it has been observed that these plants are very sensitive and highly specific to pollution free environment. Further critical study based on earlier herbarium collections, available literature and extensive field observations has revealed that its populations in the wild are depleting due to various natural and anthropogenic factors (Rao \& Deori 1980; Kataki 1986; Rao 1986; Chowdhery 1997, 1998; Lucksom 2007; Gogoi 2017). Hence, Acanthophippium striatum needs immediate in situ as well as ex situ conservation measures by orchid enthusiasts, field Botanists, Foresters and government agencies including its multiplication through micropropagation techniques. Considering the rarity and threatening status of this species, as a part of ex-situ conservation programme of rare and threatened species, some live plants were collected from road construction sites of Sessa-Zero Point BRTF in West Kameng district of Arunachal Pradesh and were introduced in the Sessa Orchid Sanctuary, Sessa. 

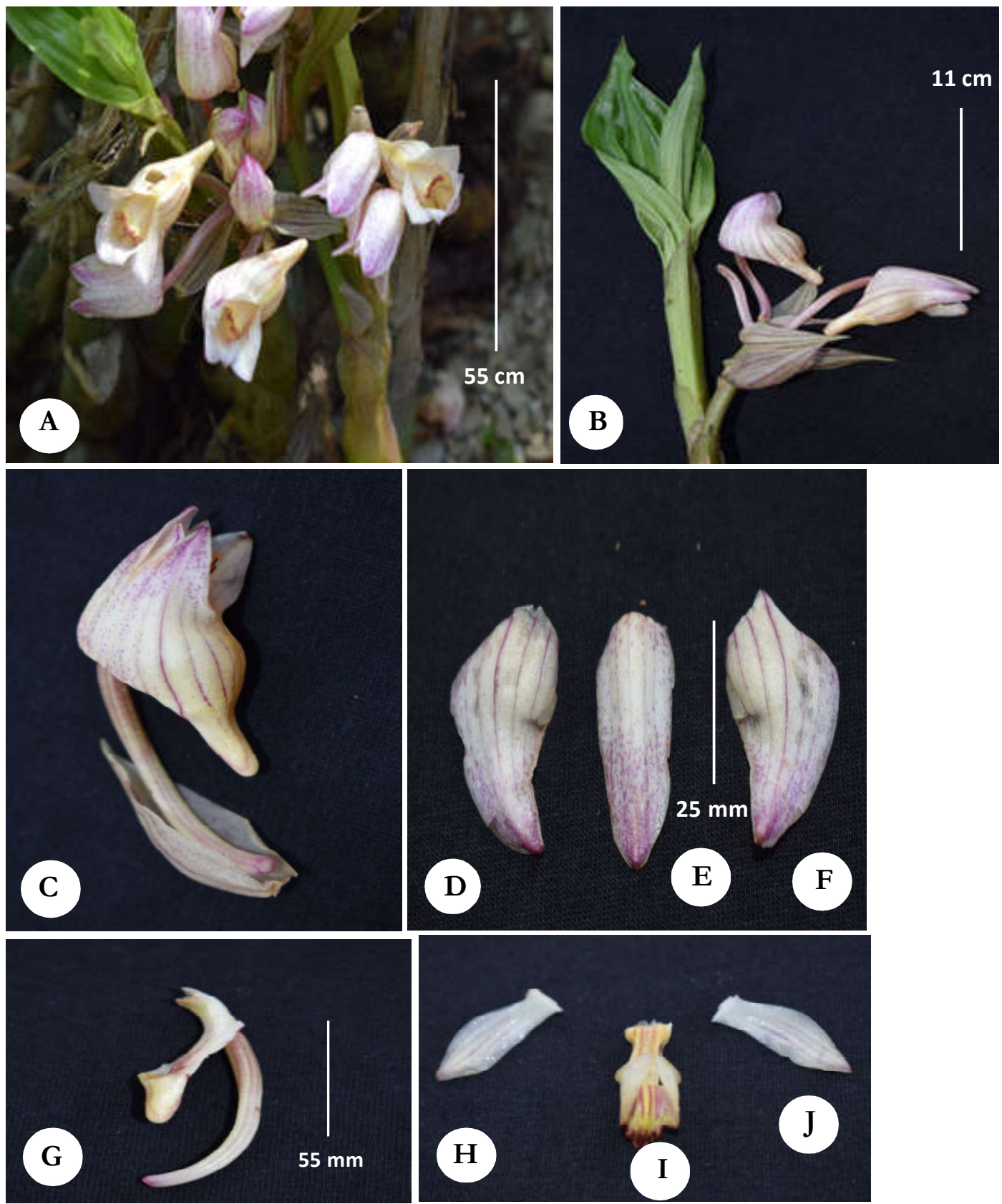

PLATE - I. Acanthophippium striatum Lindl. A. Habit; B. Inflorescence in situ closer view; C. Flower. D\&F. Lateral sepals; E. Dorsal sepal; G. Pedicellate ovary, column, foot and mentum; H \& J. Petals; I. Lip.

Acanthophippium striatum is a sub-tropical terrestrial herb, and usually prefers to grow in mild climate neither very warm nor very cold, between the altitudinal ranges of $700-2000 \mathrm{~m}$ above sea level on humid, humus-rich evergreen dense forest floor with rocky substrates of primary forests. 


\section{TAXONOMIC DESCRIPTION}

Acanthophippium striatum Lindl., Bot. Reg. 24 (Misc.): 41.1838; Hook. f., Fl. Brit. India 5: 816.1890 \& in Ann. Roy. Bot. Gard. Calc. 5: 22. 1895; King \& Pantl. in Ann. Roy. Bot. Gard. Calc. 8: 122. P1. 155. 1898; Prain, Bengal Plants: 762. 1903; Tiwari \& Mahesh. in Ind. For. 89: 427. 1963; Mehra \& Vij in Taxon 19: 106. 1970; Pradhan in Indian Orch. 2: 246. 1979; Bose \& Bhattacharjee, Orch. India: 52. 1980; Pradhan in Orch. Rev. 89 (1057): 360. 1981; S.N. Hegde in Orch. Arunachal Pradesh: 43. 1984; A. N. Rao in Bull. Arunachal Forest Res. 26 (1\&2): 88. 2010.

Terrestrial herb. Root $3 \mathrm{~mm}$ in diameter, densely pubescent. Pseudobulbs fleshy, narrowly ovoid, $6-10 \times 1-3 \mathrm{~cm}$, covered with several membranous sheaths at base and nodes, 1 - or rarely 2-leaved. Leaves solitary, petiole about $7-10 \mathrm{~cm}$ long, blade elliptic, $25-30$ x $10.5-$ $12.5 \mathrm{~cm}$, usually 5 veined, plicate. Scape lateral, arising from the base of pseudobulb, about $9-12 \mathrm{~cm}$ long, glabrous. Inflorescence with many leafy membranous sheaths; rachis densely 4 -6-flowered; floral bracts ovate-oblong, $3-3.5 \mathrm{~cm}$, apex acute. Flowers creamy white with parallel red venation, tubular, $35-45 \mathrm{~mm}$ long; pedicel and ovary $30-35 \mathrm{~mm}$, sparsely pubescent or glabrous. Dorsal sepal elliptic, $20-25 \times 10-12 \mathrm{~mm}$, 7-veined, obtuse at apex; lateral sepals oblong-triangular, slightly oblique, $26-35 \times 15-20 \mathrm{~mm}, 5-7$ veined, adnate at base to column foot to form a conico-tubular mentum, subacute and recurved at tip. Petals oblanceolate, 20-25 x 10-12 mm, fleshy, 7-veined, obtuse or acute at apex. Lip adnate to apex of column foot, $20-25 \mathrm{~mm}$, membranous, 3-lobed; lateral lobes erect, falcatetriangular, $10-12 \mathrm{~mm}$; mid-lobe with red spots or blotches, ovate-triangular, small, slightly undulate at margins, acute, recurved at tip; disk with a solitary broad yellow ridge. Column $10-15 \mathrm{~mm}$, slightly recurved towards apex; anther cap $3 \mathrm{~mm}$ broad; pollinaria 4 , yellowish, $2.2-1.5 \mathrm{~mm}$ long. Capsule $40-60 \mathrm{~mm}$ long. (Plate. I. )

Flowering: May - July.

Altitudinal range: $700-2000 \mathrm{~m}$.

Distribution: NE India (Arunachal Pradesh, Assam, Nagaland), China, Indonesia, Malaysia, Nepal, Thailand, Vietnam.

Specimens examined: Hegde 1116; Jumter Nyorak 50020 (Orchid Herbarium Tippi).

\section{Acknowledgements}

The authors are grateful to Shri Kalyan Kanti Malakar, Dy. Forest Ranger, Tippi Forest Range and all the Forest Protection Task Force of Sessa Orchid Sanctuary for extending necessary help during botanical explorations.

\section{LITERATURE CITED}

Chowdhery, H.J. 1997. Orchidaceae of Arunachal Pradesh. Bishen Singh Mahendrapal Singh, Dehradun.

Chowdhery, H.J. 1998. Orchid Flora of Arunachal Pradesh. Bishen Singh Mahendrapal Singh, Dehradun.

Deori, N. C. \& Das, G. C. 1979. Notes on rare orchids from north-eastern India-2. Bull. Bot. Surv. India 18: 233 - 235.

Gogoi, K. 2012. A checklist of Orchids in Tinsukia District of Assam, India. Pleione 6 (1): $5-26$. 
Gogoi, K. 2017. Wild Orchids of Assam. Assam State Biodiversity Board, Assam. M/S. Fairgraphics Media Services Pvt. Ltd. Bamunimaidam, Guwahati.

Hedge, S.N. 1984. Orchids of Arunachal Pradesh. Forest Department of Arunachal Pradesh, Itanagar.

Kataki, S.K.; Jain S.K.; \& Sastry, A.R.K. 1984.Threatened and Endemic Orchids of Sikkim and Northeastern India. Botanical Survey of India, Howrah.

Kataki, S.K. 1986. Orchids of Meghalaya. Govt. of Meghalaya, Shillong.

Lucksom, S.Z. 2007. The Orchid of Sikkim and North East Himalaya. Published by author, Sikkim.

Rao, A. S. and Deori, C. 1980. A preliminary census of the orchids of Kameng district, Arunachal Pradesh. Indian J. Forest. 3(3): 255 - 260.

Rao, A. N. 1986. Orchid Flora of Arunachal Pradesh - a conspectus. In: S.P. Vij (ed.), Biology, Conservation and Cultivation of Orchids. East West Press Pvt. Ltd., New Delhi. Pp. 323 - 349.

Rao, A.N. 2010. Orchid Flora of Arunachal Pradesh - An Update. Bull. Arunachal Forest Res. 26(1\&2): $82-110$.

$\mathrm{Su}$, H.J. 2000. Acanthephippium. In: Huang, T. -C. et al. (eds.). Orchidaceae. Flora of Taiwan, 2nd. Ed., Vol. 5. Editorial Committee of the Flora of Taiwan. Taipei, Taiwan. P. 379.

Thomas, S.A. 1997. Taxonomic revision of the genus Acanthephippium. In: de Vogel, E. F.(eds.) Orchid Monograph. Vol. 8. Rijksherbarium/Hortus Botanicus, Leiden, Netherlands. 8: $119-134$. 